\title{
Special Editorial
}

\section{The public in public health: the production of the common (good)}

Lucia Y. Izumi Nichiata

Universidade de São Paulo. Escola de Enfermagem. São Paulo, SP, Brasil.

University of São Paulo. School of Nursing. São Paulo, SP, Brazil.

\section{Marco Akerman}

Universidade de São Paulo. Faculdade de Saúde Pública. São Paulo, SP, Brasil.

University of São Paulo. School of Public Health. São Paulo, SP, Brazil.

\section{Marília Cristina Prado Louvison}

Universidade de São Paulo. Faculdade de Saúde Pública. São Paulo, SP, Brasil.

University of São Paulo. School of Public Health. São Paulo, SP, Brazil.

\section{Yara Maria de Carvalho}

Universidade de São Paulo. Escola de Educação Física e Esporte. São Paulo, SP, Brasil.

University of São Paulo. School of Physical Education and Sports. São Paulo, SP, Brazil.

"Truly, I live in dark times ..." said Bertold Brecht (1898-1956) in his poem To Those Who Follow in Our Wake. A sudden and disturbing time becomes challenging because it requires attention and presence, as seen on the streets in June 2013 and the recent demonstrations in March.

This is a time that demarcates a collective that, attentive to the more "nuisance," could foresee what was in production and thereby put the challenge to organize an event completely "glued" to that time and, thus, bring "darkness," not to be left " blinded by the lights" and achieve "a glimpse of those that are part of the shade, its intimate obscurity," borrowed reflections of the philosopher Agamben, in his work "What is the contemporary" of 2009, when he asks what is the contemporary time.

The Paulista Association of Public Health, reaffirms human dignity and the right to health as a permanent commitment to all, guided by the 13th Paulista Congress of Public Health, debated on the production of public as part of contemporary societies and the production of common (good), and the
Unified Health System (UHS) as an ethical-political project in dispute, but permeated by a series of successes produced by builders of citizenship.

In Congress, the discussion brought different theoretical and conceptual perspectives - human and social sciences, law and health and social movements - that characterized and marked out the speeches and debates. In addition to the dichotomy state-society and private-public, it sought to broaden the dialogue, discussing the production of the public space in relationship between users, health professionals, services, management, sectoral policies and everyday health.

The production of meanings, knowledge, policies and practices that make up the public and the common in the health sector were the topics pose as challenges to be discussed by the guests at conferences and tables. They recognized the difficulties, impediments and restrictions that are imposed on the reinvention of the public and the construction of the common, however, emphasizing the possibilities and powers that the commitment to public ethics can bring to the public and public health. Some of this material-summaries of the speeches of the speakers and panelists, and the 700 abstracts of the papers presented at the event - was gathered at the annual meeting of the 13th Paulista Congress of Public Health The public in public health - The production of the common (good).

We follow with amplification of the debate. This current issue arises every day and includes social movements and listening to the collective voice that remains, the attitudes needed to think, disputing and rearranging life in the cities. In this supplement, we were gathered texts of some lecturers and speakers who attended these events and other guests to strengthen the movement.

We open the invitation to read with de Áurea Maria Zöllner Ianni, a social scientist, professor of Health Social Sciences at the Public Health School of the University of São Paulo, who had the mandate to monitor Congress in its entirety and baste the

1 Available at: <http://apsp.org.br/wp-content/uploads/2013/og/anais-congresso-2013_05.pdf〉. Accessed on: April 22, 2015. 
main issues addressed at the event. This text makes an important contribution to the debate about the sphere of health production, claiming that in the midst of capitalist relations, which determine the "commodification" of life and the health of life, produces embarrassment and interdiction of action in the public sphere. The text is a summary of what happened at the 13th Congress and opens the discussion on one of the agendas to be discussed at the $14^{\text {th }}$ Congress, the sub-theme "decommodification of the UHS." It is also a call to continue this discussion, in São Carlos, Brazil, in September 2015, whose central theme is Health and Power: reconnecting citizens and workers to the UHS!

Peter Pál Pelbart, a philosopher and professor at the Catholic University of São Paulo, in opening the conference, and in his essay Policies of life, production of the common and life at stake, it causes us to have: "The power of a storming life!" It brings a reflection of life in the contemporary context, bodies with expropriated affections, medicalizing and taking all the power. Pelbart tells us that the philosophy of Foucault and Deleuze can help us think about the political life, the production of the common and the way to live nowadays. On the one hand, the control of society takes away any kind of breathe and powers operating inside, colonizing the future, bringing in a second axis, and the redefinition of domination: bio-potency, the power of life responding to bio-power, the power over life. The author invites us also to think about the diversity of the crowd and the common crisis at hand.

Ricardo Rodrigues Teixeira, professor at the Department of Preventive Medicine at USP, in his lecture and in his essay The dimensions of the common production and health, traces through the health field the possibility of establishing new powers of invention to overcome the production of the common. He explores in his essay, health as an affection-value and as a result of work. The naturalization of the expropriation of the common resources that occurs in our neoliberal times is more than privatization, it is deprivation of rights, where both "the market as the state contribute to the process of enclosure." Dealing with multidimensional scenarios of joint production, the author gives us as a challenge to expand sensitivity to the common health, advancing the struggle for health as a right, seeking to mobilize all accordingly. Approaching us with various works of Hardt and Antonio Negri, reminding the crowd of what is expressed and what is at work in contemporary struggles is also a self-rule learning process and inventing lasting democratic forms of social organization.

Emerson Elias Mehry, professor at the Federal University of Rio de Janeiro, in his lecture and in his essay: Crowd: sphinx of public health, place of inflection, ideas of the common good, causes us to think of the crowd like a sphinx that public health is unveiling. The crowd calls into question the government's strategies that bet on the population category as the object of health act. Negri also brings in the multiplicity of the crowd: on the one hand, there is the variety of networks of the collective stocks with constituent power of the common, setting the differentiation process and on the other hand, the capitalist order, the common as an identity, the "abnormal" to be standardized. It reflects how public health has been questioned and the possibilities built to meet the "collectives that do not give up taking care of themselves and are protagonists of their own existence, defending the radical model to show the differences in the production of wealth and so that collective life is not a substrate of inequality." We are facing new issues in the field of politics, "desiring abnormal is the capital and not the crowds!"

In the 13th Congress, the table asked What is the crisis of the modern state?, we have the presence of Marcos Orione Gonçalves Correia, Doctor of Law, professor at the Law School of USP, and Áquilas Nogueira Mendes, Doctor of Economics, professor of Health Economics at the Public Health School of USP. Both started from the assertion that it is not a government crisis but a deep and long economic crisis, a crisis of capitalism. Marcos Orione starts his text inquiring about the limited view that the production of the common good is a state responsibility. In his text he revisits Marx's texts and invites us to think about the analysis of the production of the common good from the understanding that, he states, "the state is at its most complete structure, a typical form of capitalism" and its corresponding public policies are, as such, the answer to the accumulated interests of the capital. Dealing with the 
Brazilian public health in the context of structural crisis of capitalism, Áquilas Mendes analyzes the nature of this crisis, characterized by the trend of falling profit rates and the dominance of interest-bearing capital from the last decades of the twentieth century and the impact of the ownership of capital over the social policy features of law, particularly in the universal right to health in Brazil.

Célia Maria Sivalli Campos and Cássia Baldini Soares, nurses, professors at USP School of Nursing, and Nildo Viana, a social scientist, professor at the Federal University of Goiás, take the Brazilian Unified Health System as the subject of their article, discussing how it was developed from birth in the midst of neoliberal capitalism. They also focus on the organization of Primary Care for the Family Health Program and finish the essay by highlighting the resistance and conflict paths being created from the production of emancipatory practices, such as the organization of workers, social movements and public welfare institutions.

Eduardo Passos, a psychologist, and professor in the Department of Psychology at the Fluminense Federal University and Yara M. Carvalho, graduated in Physical Education, Professor at the Department of Pedagogy of Human Movement at the University of São Paulo, cut out the theme of health education as a problematic field that is the subject of the constitutional motion of UHS as a central issue. What is the subject of this movement? How to think about training as a social practice that produces relationships and care, combining clinical and management? What is produced in relationships that call for different forms of collective contraction and creating commonality zones? Túlio Batista Franco, a psychologist, professor of psychology at the Federal Fluminense University, addresses the subjective processes of work and care. His theoretical and conceptual reference is Benedict Spinoza. From his work, he develops the idea that the worker operates with the freedom to be able to control the diseases and their contraction; to act captured by capitalistic lines, morality or science, acts in bondage. And instigates the way we think about this variation in everyday health work.

Good reading for the common good! 